\title{
TINGKAT PENGETAHUAN DAN PERSEPSI BAHAYA KOSMETIKA YANG MENGANDUNG BAHAN PEMUTIH DI SMK NEGERI 4 YOGYAKARTA
}

\author{
KNOWLEDGE AND PERCEPTION OF HAZARD COSMETICS \\ CONTAINING BLEACHING AGENT IN SMK STATE 4 YOGYAKARTA
}

Deni Lisnawati, Agustin Wijayanti, Ade Puspitasari

Politeknik Kesehatan Bhakti Setya Indonesia

Email: agustinwijayanti97@yahoo.com

\begin{abstract}
ABSTRAK
Penelitian ini dilatarbelakangi banyaknya kosmetika dengan bahan berbahaya yang terkandung di pasaran. Selama tahun 2014 ditemukan 68 kosmetikaa mengandung bahan berbahaya, baik produk impor maupun lokal. Produk-produk tersebut telah ditarik dari peredaran karena akan membahayakan konsumen. Pada hasil studi pendahuluan yang dilakukan pada 56 siswi di SMK Negeri 4 Yogyakarta, khususnya jurusan tata kecantikan sebagian besar masih kurang pemahamannya tentang bahaya kosmetika yang mengandung bahan pemutih. Penelitian ini bertujuan untuk mengetahui bagaimana tingkat pengetahuan dan persepsi siswi-siswi kelas XI terhadap bahaya kosmetika yang mengandung bahan pemutih, serta darimana saja sumber informasi siswi-siswi kelas XI tentang bahaya kosmetika yang mengandung bahan pemutih. Penelitian ini menggunakan metode deskriftif dirancang secara kualitatif dan kuantitatif. Subyek dalam penelitian ini adalah siswi kelas XI SMK Negeri 4 Yogyakarta jurusan tata kecantikan sebanyak 56 siswi dan teknik pengumpulan data menggunakan metode Quota sampling. Alat pengambil data adalah kuesioner tertutup dan dianalisa secara deskriptif. Hasil penelitian pengetahuan siswi kelas XI tentang bahaya kosmetika yang mengandung bahan pemutih yaitu 51,8\% yang sebagian besar sudah cukup mengetahui tentang kosmetika yang mengandung bahan pemutih. Persepsi siswi-siswi kelas XI tentang bahaya kosmetika yang mengandung bahan pemutih berbahaya dapat merusak kulit, dapat menyebabkan kanker, lebih berwaspada, berhati-hati dalam memilih kosmetika dan jangan digunakan (sebaiknya dimusnahkan). Sumber informasi pengetahuan kosmetika yang mengandung bahan pemutih yaitu sosial media, iklan di TV, brosur, teman sekolah dan guru di sekolah.
\end{abstract}

Kata kunci: Pengetahuan, Persepsi, pemutih, kosmetika berbahaya 


\begin{abstract}
This study was motivated by many cosmetics with hazardous ingredients on the market. During 2014 found 68 kosmetikaa contain hazardous materials, both imported and local products. Such products have been withdrawn from circulation because it would harm consumers. In the preliminary study conducted on 56 female students at SMK Negeri 4 Yogyakarta, especially the beauty department layout is still largely lacking understanding of the dangers of cosmetics containing bleach. This study aims to determine how the level of knowledge and perception of female students in class XI against the dangers of cosmetics that contain whitening ingredients, as well as resources from anywhere female students in class XI of the dangers of cosmetics containing bleach. This study used a descriptive method designed qualitatively and quantitatively. The subjects in this study is a class XI student of SMK Negeri 4 Yogyakarta majoring in beauty procedures as much as 56 schoolgirls and data collection using Quota sampling. The data was obtained closed questionnaire and analyzed descriptively. The results of class XI student knowledge about the dangers of cosmetics containing a bleaching agent was $51.8 \%$ which is mostly already know enough about cosmetics that contain bleach. Perception of female students in class XI of the dangers of cosmetics containing harmful bleaching agents can damage the skin, can cause cancer, Awareness, be careful in choosing cosmetics and should not be used (preferably eliminated). Sources of information and knowledge of cosmetics containing a bleaching agent obtained from social media, advertising on $T V$, brochures, school friends and teachers at school.
\end{abstract}

Keywords: Awareness, Perceptions, bleach, harmful cosmetic

\title{
PENDAHULUAN
}

Kosmetika adalah bahan atau sediaan yang dimaksudkan untuk digunakan pada bagian luar tubuh manusia (epidermis, rambut, kuku, bibir dan organ genital bagian luar) atau gigi dan membran mukosa mulut terutama untuk membersihkan, mewangikan, mengubah penampilan dan atau memperbaiki bau badan atau melindungi atau memelihara tubuh padakondisi baik (BPOM RI, 2011).

Kosmetika saat ini sudah menjadi kebutuhan penting bagi manusia. Kosmetika tidak hanya digunakan untuk fungsi estetika, akan tetapi berperan dalam penyembuhan dan perawatan kulit. Meski bukan merupakan kebutuhan primer, namun kosmetika merupakan salah satu produk yang digunakan rutin dan terus-menerus oleh manusia. Oleh karena itu keamanan kosmetika dari bahanbahan berbahaya perlu diperhatikan. Kosmetika merupakan produk yang 
diformulasi dari berbagai bahan-bahan aktif dan bahan-bahan kimia yang akan bereaksi ketika diaplikasikan pada jaringan kulit (Muliyawan dan Suriana, 2013). Bahan berbahaya adalah bahan-bahan aktif yang menimbulkan reaksi negatif dan berbahaya bagi kesehatan kulit khususnya dan tubuh umumnya ketika diaplikasikan, baik dalam jangka panjang maupun jangka pendek (Muliyawan dan Suriana, 2013).

Di Indonesia angka kejadian efek samping kosmetik juga cukup tinggi terbukti dengan selalu di jumpainya kasus efek samping kosmetik pada praktek seorang dermatologi. Reaksi efek samping kosmetik cukup parah akibat penambahan bahan aditif untuk meningkatkan efek pemutih. Parahnya reaksi efek samping kosmetik ini salah satunya disebabkan karena penambahan bahan aditif untuk meningkatkan efek pemutih, disamping karena penggunaan jangka panjang pada area yang luas pada tubuh, di iklim yang panas dan lembab yang kesemuanya meningkatkan absorbsi melewati kulit. Reaksi negatif yang ditimbulkan oleh bahan berbahaya yang terkandung dalam kosmetika beragam, mulai dari iritasi ringan hingga berat, alergi, penyumbatan fisik di pori-pori, keracunan lokal atau sistemik. Reaksi negatif ini tidak hanya berdampak pada jaringan kulit, tetapi dampaknya bisa lebih luas. Bahkan berpengaruh pada sistem jaringan dan organ-organ penting lainnya (Muliyawan dan Suriana, 2013). Saat ini kosmetika mengandung bahan berbahaya banyak beredar di masyarakat. Hal itu terjadi karena masih banyak permintaan masyarakat yang menginginkan efek instan terutama untuk perawatan kulit, badan atau memberikan penampilan yang cantik dengan harga murah atau terjangkau. Selama tahun 2014 ditemukan 68 kosmetikaa mengandung bahan berbahaya, baik produk impor maupun lokal. Produk-produk tersebut telah ditarik dari peredaran karena akan membahayakan konsumen (BPOM RI, 2014).

Hasil investigasi dari Badan Pengawas Obat dan Makanan (BPOM) masih banyak ditemukan sediaan kosmetik yang tidak memenuhi standar yang ditetapkan oleh Departemen Kesehatan RI. Berdasarkan hasil pengawasan Badan POM selama tahun 2014 diidentifikasi 68 kosmetika mengandung bahan berbahaya, terdiri dari 32 kosmetika luar negeri dan 36 kosmetika dalam negeri. 
Berdasarkan daftar lampiran Public Warning No. HM.03.03.1.43.12.14.7870 tanggal 19 Desember 2014 oleh Badan Pengawas Obat dan Makanan, terdapat beberapa sediaan kosmetik yang diantaranya lipstik, krim malam, sabun wajah, eye shadow, blush on, dan bedak. Kosmetika tersebut mengandung bahan berbahaya seperti logam timbal, merkuri, pewarna merah K3, dan bahan berbahaya lainnya. Kosmetika yang termasuk ke dalam peringatan publik atau public warning mengandung bahan berbahaya tersebut terdiri dari 37 kosmetika yang tidak ternotifikasi dan 31 memiliki nomor notifikasi yang telah dibatalkan (BPOM RI, 2014).

Pemilihan responden siswi-siswi SMK Negeri 4 Yogyakarta dilakukan karena penulis ingin meneliti tentang tingkat pengetahuan dan persepsi siswisiswi kelas XI tentang bahaya kosmetika yang mengandung bahan pemutih. Berdasarkan observasi awal yang dilakukan pada 56 siswi di SMK Negeri 4 Yogyakarta, khususnya jurusan tata kecantikan, masih ada diantara mereka mengalami kesulitan dalam mengetahui dan memberikan persepsi tentang bahaya kosmetika yang mengandung bahan pemutih.

\section{METODE PENELITIAN}

Rancangan penelitian ini adalah penelitian deskriptif, data yang digunakan adalah data kualitatif dan kuantitatif. Data kualitatif diperoleh dari data hasil analisa tingkat pengetahuan dan persepsi siswi kelas XI di SMK Negeri 4 Yogyakarta tentang bahaya kosmetika yang mengandung bahan pemutih.

Populasi penelitian ini adalah siswi SMK Negeri 4 Yogyakarta yang terdaftar sebagai siswi jurusan kecantikan kelas XI. Besar Sampel menggunakan teknik total sampling sebanyak 56 responden.

Kriteria Inklusi dari penelitian ini sebagai berikut: 1) Siswi terdaftar sebagai siswa SMK Negeri 4 Yogyakarta Jurusan Tata Kecantikan kelas XI. 2) Siswi yang tercatat sebagai warga Kecamatan Magetan. 3) Bersedia menjadi responden dan mengikuti prosedur penelitian. 4) Siswi usia 15-17 tahun. Kriteria eksklusi pada penelitian ini: 1) Mengetahui jenis-jenis kosmetika. 2) Mengenal fungsi dari kosmetika. 3) Menggunakan kosmetika. 
Bahan yang akan digunakan dalam penelitian adalah data yang merupakan hasil dari jawaban responden. Alat yang digunakan untuk pengambil data adalah menggunakan kuesioner. Penelitian ini menggunakan kuesioner dengan pertanyaan tertutup sebanyak 18 item untuk mengukur tingkat pengetahuan responden serta kuisioner terbuka sebanyak 5 item untuk mengukur persepsi dari responden.

Analisis Data terhadap:

1. Tingkat pengetahuan diukur menggunakan kuesioner, jika jawaban benar diberi skor 1 dan jawaban salah diberi skor 0 , kemudian dihitung dengan persentase.

Tingkat pengetahuan $(\%)=\frac{\text { Jumlah jawaban benar }}{\text { Jumlah seluruh skor jawaban tertinggi }} \times 100 \%$

Berdasarkan hasil jawaban kuesioner tersebut, maka dapat ditentukan klasifikasi tingkat pengetahuan menjadi :

a. Pengetahuan baik jika: 76-100\% jawaban benar

b. Pengetahuan cukup jika 56-75\% jawaban benar

c. Pengetahuan kurang jika $<56 \%$ jawaban benar

(Arikunto, 2006)

2. Persepsi siswi SMK dianalisa berdasarkan hasil pembahasan dari kuesioner terbuka yang berisi jawaban dan tanggapan dari responden terhadap kosmetika dengan bahan pemutih yang berbahaya.

Kuesioner dilakukan uji validitas sebelum digunakan di SMK Muhamadiyah Nitikan jurusan Tata Kecantikan kelas XI. Lokasi uji validitas dipilih dengan mempertimbangkan kemiripan kondisi dari responden. Hasil uji validitas ditunjukkan dengan taraf signifikansi $0,05 \mathrm{r}$ hitung $\geq \mathrm{r}$ tabel dengan sig. 0,05 .

\section{HASIL DAN PEMBAHASAN}

Berdasarkan data yang terkumpul dari 56 siswi di SMK Negeri 4 Yogyakarta, diperoleh hasil umur responden yang tersaji pada Tabel I. 
Tabel I. Umur Responden

\begin{tabular}{cccc}
\hline No & $\begin{array}{c}\text { Umur } \\
\text { (tahun) }\end{array}$ & $\mathbf{N}$ & $\mathbf{F}(\boldsymbol{\%})$ \\
\hline 1 & 15 & 13 & 23,2 \\
2 & 16 & 26 & 46,4 \\
3 & 17 & 17 & 30,4 \\
\hline \multicolumn{2}{r}{ Total } & 56 & 100 \\
\hline
\end{tabular}

Siswi-siswi SMK Negeri 4 Yogyakarta memiliki usia yang berbeda. Perbedaan usia remaja putri berpengaruh terhadap pengetahuan dan persepsi terhadap bahaya kosmetika yang mengandung bahan pemutih. Seperti yang dikemukakan oleh Rumini (2004), bahwa masa remaja merupakan masa peralihan dari masa anak menjadi masa dewasa yang mengalami perkembangan semua aspek atau fungsi untuk memasuki masa dewasa menunjukkan perubahan yang jelas, sifat transisi atau peralihan karena remaja belum memperoleh status dewasa dan tidak lagi memiliki status anak.

Pada masa ini anak mengalami masa pertumbuhan dan masa perkembangan fisik maupun perkembangan psikis. Mereka bukanlah anak-anak, baik bentuk badan ataupun cara berfikir atau bertindak, tetapi bukan pula orang dewasa yang telah matang. Batasan usia remaja yang umum digunakan oleh para ahli adalah antara 12 hingga 21 tahun. Rentang waktu usia remaja ini biasanya dibedakan atas tiga tahap, yaitu 12-15 tahun merupakan masa remaja awal, 15-18 tahun merupakan masa remaja pertengahan dan 18-21 tahun merupakan masa remaja akhir. Penelitian yang dilakukan di SMK Negeri 4 Yogyakarta memiliki karakteristik responden remaja pertengahan yaitu 15-18 tahun karena rata-rata usia responden 15,16 dan 17 tahun dengan ciri khas diantaranya sedang mencari identitas diri dan mengembangkan kemampuan berpikir abstrak.

Berdasarkan Tabel II, dapat diketahui bahwa pengetahuan siswi SMK Negeri 4 tentang bahaya kosmetika yang mengandung bahan pemutih sebagian besar cukup yaitu 29 responden $(51,8 \%)$. Salah satu indikator tingkat pengetahuan kosmetika berbahaya mengandung bahan pemutih di SMK Negeri 4 Yogyakarta 
dalam penelitian ini adalah pengetahuan siswi tentang zat-zat yang berbahaya yang tekandung di dalam kosmetika.

Tabel II. Pengetahuan tentang Kosmetik Berbahaya

\begin{tabular}{clcc}
\hline No & Kategori & N & F(\%) \\
\hline 1 & Baik & 15 & 26,8 \\
2 & Cukup & 29 & 51,8 \\
3 & Kurang & 12 & 21,4 \\
& Total & 56 & 100 \\
\hline
\end{tabular}

Menurut Wawan (2010), faktor-faktor yang mempengaruhi pengetahuan terdiri dari faktor internal (pendidikan, minat, umur) dan ekternal (lingkungan dan informasi). Faktor internal yang mempengaruhi responden berkaitan dengan faktor usia responden yang masih dalam masa remaja pertengahan dimana mereka masih mengalami masa transisi dari anak-anak menuju dewasa.

Hasil penelitian ini sejalan dengan penelitian Dwi (2014) yaitu pengetahuan tentang kosmetikaa riasan pada mahasiswi di Universitas Negeri Padang yang menunjukkan bahwa sebagian besar mahasiswi memiliki kategori pengetahuan cukup sebesar $80 \%$ terhadap kosmetika berbahan sehat untuk riasan. Peneliti menggambarkan penelitian tentang pengetahuan sama halnya dengan tingkat pengetahuan dan persepsi dikarenakan berdasarkan definisi operasional dalam penelitian ini dimana pengetahuan yang baik mengenai kosmetika berbahaya yang mengandung bahan pemutih akan berbanding lurus dengan tingkat pengetahuan dan persepsi kosmetika berbahaya mengandung bahan pemutih. Hal ini dibuktikan dengan proses terjadinya persepsi yang dikemukakan Widiyatun (2009) yakni adanya stimulus berupa informasi mengenai pengetahuan kosmetika kemudian akan diproses dalam memori otak sehingga terciptalah persepsi. Stimulus berupa informasi mengenai kosmetika yang diterima akan berpengaruh kepada tingkat pengetahuan dan persepsi responden tentang kosmetika.

Parameter yang peneliti gunakan untuk mengetahui tentang tingkat pengetahuan tentang bahaya kosmetika yang mengandung bahan pemutih bagi responden menggunakan kuesioner tertutup (18 butir soal), sedangkan untuk persepsi menggunakan kuesioner terbuka (5 soal essay). 
Berikut ini adalah pembahasan dari jawaban-jawaban yang diberikan dalam kuesioner terbuka :

1. Pertanyaan No.1 tentang mengapa para responden menggunakan kosmetika, sebagian besar responden yang memakai bahan kosmetika menyadari bahwa kosmetika diperlukan untuk menunjang penampilan, keinginan tampil cantik dan lebih baik serta juga dapat merawat kesehatan kulit. Sebagian kecil menyadari bahwa kosmetika belum diperlukan dalam perawatan kulit mereka.

2. Pada pertanyaan No.2 mengenai bahan berbahaya yang dilarang digunakan dalam kosmetika sebagian besar responden menjawab merkuri, hidroquinon. Responden masih beranggapan bahwa bahan yang berbahaya hanya kedua bahan tersebut. Responden belum mengetahui bahwa masih banyak jenis bahan berbahaya yang dilarang dalam penggunaan kosmetika seperti asam retinoat, bahan pewarna, K3, K10 dan lain-lain. Minimnya informasi mengenai bahan berbahaya yang dilarang dalam penggunaan kosmetika akan menimbulkan persepsi yang kurang terhadap kosmetika pemutih yang mengandung bahan berbahaya. Sehingga secara tidak sadar para sisiwi menggunakan kosmetika yang berbahaya bagi kesehatan mereka. Mulyawan (2013), menyatakan bahwa sebelum memutuskan untuk menggunakan kosmetikaa, seharusnya diikuti dengan pengetahuan tentang ciri-ciri kosmetika berbahaya.

3. Pertanyaan No. 3 adalah apakah para responden meyakini bahwa kosmetika yang mereka gunakan aman. Sebagian besar para siswi menjawab "Insya Allah yakin" karena kosmetika yang mereka gunakan aman karena telah mendapat informasi dari teman, iklan di TV atau sosial media. Namun, tidak sedikit yang menjawab bahwa tidak begitu yakin terhadap kosmetika yang mereka gunakan.

4. Pertanyaan No. 4 tentang tanggapan responden terhadap kosmetika dengan bahan pemutih berbahaya adalah sebagian besar responden menjawab jika menggunakan bahan pemutih tidak berlebihan tidak masalah. Responden selama menggunakan kosmetika pemutih berbahaya dan tidak merasakan reaksi negatif seperti gatal-gatal, rasa panas serta efek jangka panjang berupa kanker, flek, kemandulan dan lain-lain. Hal ini dikarenakan pengetahuan tentang 
kosmetika berbahaya para responden masih dalam kategori cukup sehingga belum seluruh responden memiliki pengetahuan yang baik tentang kosmetika berbahaya mengandung bahan pemutih.

5. Pertanyaan No. 5 adalah mengenai dari mana informasi yang mereka peroleh tentang kosmetika yang mereka gunakan. Responden mendapatkan informasi tentang kosmetika dari teman, internet, perpustakaan sekolah, iklan di TV dan sebagian besar dari label kemasan kosmetika yang mereka lihat.

6. Berdasarkan analisa sebagian besar responden mengetahui dengan baik tentang tujuan menggunakan kosmetika, kosmetika yang sehat bagi kulit dan cara melihat kosmetika yang legal.

Persepsi tentang bahaya kosmetika yang mengandung bahan pemutih yang didapat dari responden sangat beragam, karena persepsi tersebut merupakan penilaian dari para siswi yang dilatarbelakangi oleh berbagai faktor diantaranya pengetahuan, pengalaman, usia dan kepribadian. Bagi banyak wanita, muncul mode atau trend baru yang sangat mempengaruhi penampilan dan sering menjadi perhatian salah satunya adalah kulit. Banyaknya wanita yang menginginkan kulit wajah terlihat lebih putih karena kulit putih itu identik dengan cantik seperti yang dapat dilihat pada Tabel III.

Tabel III. Alasan responden menggunakan kosmetika

\begin{tabular}{ll}
\hline \multicolumn{1}{c}{ Pernyataan responden } & $\begin{array}{c}\text { Jumlah } \\
(\%)\end{array}$ \\
\hline Untuk menunjang penampilan/ merawat wajah & $25(44,6)$ \\
Agar wajah terlihat bersih dan menarik/ indah & $9(16,2)$ \\
Ingin mempercantik diri & $9(16,2)$ \\
Karena kosmetik dapat membuat wajah terlihat lebih cantik & $6(10,7)$ \\
Iya & $3(5,4)$ \\
Untuk merawat kulit dan tubuh & $1(1,8)$ \\
Lebih percaya diri & $1(1,8)$ \\
Karena wajah membutuhkan & $1(1,8)$ \\
Untuk menjaga dari paparan sinar matahari & $1(1,8)$ \\
\hline
\end{tabular}

Tingginya keinginan untuk memiliki kulit putih sering membuat seseorang mengabaikan informasi yang utuh tentang kosmetika yang mereka pergunakan. Efek yang cepat dan harga murah merupakan faktor yang selalu diinginkan 
konsumen terhadap kosmetika, terkadang tanpa memperhatikan keamanan dari kosmetika tersebut. Hal ini selaras dengan hasil penelitian yang dilakukan oleh Abu (2005) yang menyatakan bahwa jika seseorang telah memiliki keinginan yang kuat akan sesuatu hal maka orang tersebut tidak akan mencari informasi tambahan tentang obyek yang mereka inginkan. Terkait dengan besarnya keinginan menjadi cantik dan putih karena penggunaan kosmetika terlihat pada Tabel IV, V dan VI.

Tabel IV. Pendapat Responden Tentang Bahan Pemutih Berbahaya

\begin{tabular}{lc}
\hline \multicolumn{1}{c}{ Pernyataan responden } & Jumlah \\
\hline Merkuri & 19 \\
Merkuri, pemutih & 15 \\
Merkuri, borak & 8 \\
Tidak tahu & 5 \\
Merkuri, hidrokinon & 5 \\
Merkuri, hidrikunion, pemutih, pengawet & 2 \\
Boraks & 1 \\
Merkuri, rodhamin & 1 \\
\hline
\end{tabular}

Tabel V. Pendapat Responden tentang Keamanan Kosmetika yang Digunakan

\begin{tabular}{lc}
\hline \multicolumn{1}{c}{ Pernyataan responden } & Jumlah \\
\hline Yakin & 18 \\
Iya. Karena didalam kosmetik sudah ada label BPOM/ sudah lulus uji BPOM dan departemen & 14 \\
$\quad$ kesehatan & 9 \\
Insya Allah & 3 \\
Insya Allah aman. Belum menimbulkan efek samping & 2 \\
Tidak yakin, karena saya belum tahu pembuatannya & 2 \\
Tidak. Karena kosmetik dalam kemasan pasti mengandung pengawet dan bahan kimia & \\
$\quad$ berbahaya jika digunakan dalam jangka waktu lama akan menimbulkan kerusakan pada & \\
$\quad$ jaringan, tetapi jika menggunakan kosmetik yang terbuat dari bahan alami jauh lebih baik. & 1 \\
Tidak. Terdapat banyak merkuri & 1 \\
Yakin. Karena selama penggunaan, tidak ada reaksi negatif dari kulit saya & 1 \\
Aman karena sudah teruji oleh dokter & 1 \\
Tidak. Karena tidak semua kosmetik terdaftar & 1 \\
Tidak tahu & 1 \\
Insya Allah aman. Karena tidak menyebabkan kulit saya iritasi & 1 \\
Yakin. Karena sudah banyak yang membuktikan dan berani mengiklankan di TV & 1 \\
Tidak. Karena semua kosmetik megandung pengawet atau bahan kimia lainnya & 18 \\
Yakin & 14 \\
Iya. Karena didalam kosmetik sudah ada label BPOM/ sudah lulus uji BPOM dan departemen & \\
$\quad$ kesehatan & 9 \\
Insya Allah & 3 \\
Insya Allah aman. Belum menimbulkan efek samping & 3 \\
\hline
\end{tabular}


Tabel VI. Pendapat Responden tentang Kosmetika Pemutih

\begin{tabular}{lc}
\hline \multicolumn{1}{c}{ Pernyataan responden } & Jumlah \\
\hline Menggunakan bahan pemutih jika tidak berlebihan tidak bermasalah & 12 \\
Tidak baik, sebaiknya jangan digunakan & 9 \\
Jika pemakaian berlebihan bisa berbahaya & 6 \\
Kosmetik yang mengandung bahan pemutih sangat berbahaya bagi kulit & 5 \\
Berhati-hati dalam menggunakan memilih sebuah kosmetik & 4 \\
Tidak baik, sebaiknya jangan digunakan & 9 \\
Jika pemakaian berlebihan bisa berbahaya & 6 \\
Kosmetik yang mengandung bahan pemutih sangat berbahaya bagi kulit & 5 \\
Berhati-hati dalam menggunakan memilih sebuah kosmetik & 4 \\
Kosmetik sangat berbahaya jika digunakan terus menerus & 1 \\
Proses reaksi dikulit sangat cepat & 1 \\
Bisa merusak kulit & 1 \\
Jika bahan pemutih berbahaya sebaiknya segera dihentikan & 1 \\
Jika memakai kosmetik tersebut lama-lama membahayakan & 1 \\
Jika dipakai dalam jangka panjang dapat menyebabkan kanker kulit dan berbahaya & 1 \\
Sebaiknya waspada dan jangan terpengaruh ingin cepat putih & 1 \\
Jika terlalu banyak, membahayan diri & 1 \\
Sebaiknya dimusnahkan & 1 \\
\hline
\end{tabular}

Banyaknya kosmetika yang beredar di pasaran mempersulit responden dalam memilih kosmetika (Prasetijo dan Ihalauw, 2005). Tabel VII menunjukkan sumber informasi responden tentang kosmetika.

Tabel VII. Sumber informasi tentang kosmetika yang digunakan

\begin{tabular}{lc}
\hline \multicolumn{1}{c}{ Pernyataan responden } & Jumlah \\
\hline Dari informasi yang terdapat pada bungkus kosmetik & 14 \\
Iklan, teman & 11 \\
Dari iklan & 5 \\
Dari teman dan dokter pribadi & 4 \\
Karena saya sudah mencoba segala kosmetik dan kosmetik yang cocok & 4 \\
yang saya gunakan & 4 \\
Internet, orang tua, guru kejuruan kecantikan, label & 2 \\
Dari iklan tv, internet & 2 \\
Internet & 2 \\
Dari televisi dan dari label yang tertera & 1 \\
Promosi & 1 \\
Dari sebuah dokter di panti rapih & 1 \\
Tidak tahu & 1 \\
Dari sejarah kosmetik sejak zaman dulu kala dan orang tua & 1 \\
Dari berbagai informasi seperti brosur, iklan dan teman. & 1 \\
Online shop dan mbah google dan dari dokter kulit & 1 \\
Dari iklan yang dipasang dan dari banyak orang yang telah memakai & \\
kosmetik tersebut & 1 \\
Internet, sekolah, buku, guru dan label dalam kosmetik & \\
\hline
\end{tabular}




\section{KESIMPULAN}

Pengetahuan siswi SMK Negeri 4 Yogyakarta tentang bahaya kosmetika dengan kandungan bahan pemutih memiliki pengetahuan dengan kategori baik, cukup, dan kurang berturut-turut sebesar 26,8\%, 51,8\%, dan 21,4\%. "Menggunakan bahan pemutih jika tidak berlebihan tidak bermasalah" merupakan persepsi terbanyak dari siswi tentang bahaya kosmetika yang mengandung bahan pemutih.

\section{UCAPAN TERIMAKASIH}

Pada kesempatan ini kami ucapkan terimakasih tak terhingga atas segala bantuan, masukan serta kritik sarannya kepada yang terhormat :

1. Direktur beserta staf Rumah Sakit PKU Muhammadiyah Yogyakarta yang telah memberikan ijin dalam melaksanakan penelitian ini.

2. Dra. Yuli Puspito Rini, M.Si. selaku Direktur Politeknik Kesehatan Bhakti Setya Indonesia Yogyakarta.

3. Nur Ismiyati, M.Sc, Apt. selaku Ketua Program Studi D3 Farmasi Politeknik Kesehatan Bhakti Setya Indonesia Yogyakarta.

4. Keluarga besar SMK Negeri 4 Yogyakarta atas ijin serta kesempatan yang diberikan untuk dapat melakukan penelitian.

\section{DAFTAR PUSTAKA}


Abu, 2009, Psikologi Belajar, Rineka Cipta, Jakarta : 20-30.

Arikunto dan Suharsimi, 2006, Prosedur Penelitian Suatu Pendekatan Praktik, Rineka Cipta, Jakarta : 168-170.

BPOM RI, 2014, Peraturan Kepala Badan Pengawas Obat dan Makanan RI No. HM.03.03.1.43.12.14.7870 tentang Kosmetika yang Mengandung Bahan Berbahaya, Biro Hukum dan Hubungan Masyarakat Badan Pengawas Obat dan Makanan, Jakarta : 6-22.

BPOM RI, 2011, Peraturan Kepala Badan Pengawas Obat dan Makanan RI No. HK.03.1.23.08.11.07517 tentang Persyaratan Teknis Bahan Kosmetika, Direktorat Standarisasi Obat Tradisional, Kosmetika dan Produk Komplemen Badan Pengawas Obat dan Makanan Repuplik Indonesia, Jakarta: 20.

Dwi, S, 2014, Pengetahuan tentang Kosmetika Riasan pada Mahasiswi di Universitas Negeri Padang, Skripsi, Universitas Negeri Padang : 49.

Muliyawan D. dan Suriana N., 2013, A-Z tentang Kosmetika, PT Elex Media Komputindo, Jakarta: 38-115.

Prasetijo dan Ihalauw, 2005, Prilaku Konsumen, Penerbit Andi, Yogyakarta: 2332.

Rumini, S. dan Sundari, S. 2004. Psikolog Perkembangan Anak dan Remaja, Rineka Cipta, Jakarta : 54-56.

Wawan, A. dan M. Dewi, 2010, Teori dan Pengukuran Pengetahuan, Sikap, dan Perilaku Manusia, Nuha Medika, Yogyakarta: 11-18

Widiyatun, T.R., 2009, Ilmu Prilaku, Edisi Kedua, Sagung Seto, Jakarta: 103132. 